\title{
Aplikasi Elektronik Arsip (E-Arsip) Surat Berbasis Web Menggunakan Metode First In First Out (FIFO)
}

\author{
Wahyu Suratman ${ }^{1}$, Fauziah ${ }^{2}$, Ratih Titi Komala Sari ${ }^{3}$ \\ ${ }^{1}$ Fakultas Teknologi Komunikasi dan Informatika Universitas Nasional \\ e-mail: wahyu.suratman062@gmail.com \\ ${ }^{2}$ Fakultas Teknologi Komunikasi dan Informatika Universitas Nasional \\ e-mail: fauziah@civitas.unas.ac.id \\ ${ }^{3}$ Fakultas Teknologi Komunikasi dan Informatika Universitas Nasional \\ e-mail: ukhuwahku01@gmail.com
}

\begin{abstract}
Abstrak - Penelitian ini bertujuan untuk mengoptimalisasi penggunaan Aplikasi kearsipan surat berupa surat masuk dan surat keluar yang digunakan oleh staf atau pegawai instansi di Universitas Nasional. Pada tahap analisis ditemukan masalah dalam Aplikasi pengelolaan kearsipan surat di Universitas Nasional yaitu masih menggunakan proses manual dalam mengarsipkan surat seperti menggunakan buku catatan arsip dalam mencatat surat masuk dan surat keluar dan surat yang disimpan dalam lemari dikelompokan sesuai jenisnya. Hal tersebut menyebabkan proses pengolahan surat masuk dan surat keluar menjadi lambat. Selain itu menurut jumlah data statistik jumlah surat masuk dan keluar semakin banyak contoh pada tahun 2020 berjumlah 1000 surat. Berdasarkan latar belakang masalah tersebut peneliti membuat suatu aplikasi elektronik arsip (e-arsip) surat berbasis web di Universitas Nasional. Aplikasi dibuat menggunakan bahasa pemograman PHP dengan framework CodeIgniter dan database MySQL. Adapun metode tambahan yang digunakan yaitu metode First In First Out (FIFO). Metode FIFO dilakukan seperti proses antrian, dimana surat yang pertama kali masuk akan diproses terlebih dahulu kemudian surat berikutnya.
\end{abstract}

Kata Kunci: Aplikasi elektronik arsip (e-arsip), metode FIFO, CodeIgniter, MySQL, surat elektronik

Abstract - This study aims to optimize the use of a mail filing system in the form of incoming and outgoing letters used by staff or agency employees at the National University. At the analysis stage, problems were found in the incoming and outgoing mail archive management system at the National University, namely still using manual processes in filing letters such as using archival notebooks in recording incoming and outgoing letters and filing letters stored in cabinets and grouped according to similar documents. This causes the processing of incoming and outgoing mail to be slow. In addition, according to the number of statistical data, the number of incoming and outgoing letters is getting more and more examples in 2020 amounting to 1000 letters. Based on the background of the problem, a solution can be obtained, namely making an electronic application for web-based mail archives (e-archives) at the Universitas Nasional. The web-based e-archive mail application was created using the PHP programming language with the CodeIgniter framework and MySQL database. The additional method used is the First In First Out (FIFO) method. The FIFO method is carried out like a queuing process, where the first incoming letter will be processed first and then the next letter.

Keywords: electronic archive Application (e-archives), electronic letter, FIFO method,, CodeIgniter, MySQL

\section{PENDAHULUAN}

\section{Latar Belakang}

Seiring berkembangnya kemajuan teknologi informasi, semua golongan masyarakat termasuk dosen, mahasiswa, dan staf perguruan tinggi tergerak untuk ikut maju dan memanfaatkannya. Perkembangan teknologi informasi juga berkembang pada bidang akademik yang dapat digunakan untuk meningkatkan efisiensi dan efektivitas proses akademik. Salah satunya yaitu pada proses pengarsipan surat di Universitas Nasional. Pada proses pengarsipan surat di Universitas Nasional masih menerapkan Aplikasi pengarsipan manual seperti masih menggunakan buku catatan arsip dalam mencatat surat masuk dan surat keluar dan pengarsipan surat disimpan dalam 
lemari dan dikelompokan sesuai dengan dokumen yang sejenis. Pengarsipan secara manual dapat menyebabkan kerusakan, surat hilang dan menyulitkan pencarian surat jika suatu saat diperlukan sebuah aplikasi.

Aplikasi merupakan unit perangkat lunak yang dibuat untuk memenuhi kebutuhan berbagai aktivitas ataupun pekerjaan, seperti aktivitas perbankan, layanan masyarakat, periklanan, dan berbagai aktivitas lainnya yang dilakukan oleh manusia. (Hendrayudi, 2013).

Aplikasi kearsipan elektronik memiliki kabinet virtual yang di dalamnya berisi map virtual atau

folder dibanding dengan kearsipan konvensional yang menyimpan dokumen penting dalam kabinet berbentuk fisik. Selanjutnya di dalam folder akan berisi arsip yang sudah dikonversi ke dalam bentuk file gambar (.png, .jpg, dll) atau dokumen (.doc, .pdf, .txt, dll). (Hatta et al., 2019). Menurut Amsyah arsip adalah setiap catatan/record/warkat yang tertulis, tercetak atau ketikan dalam bentuk huruf, angka atau gambar, yang memiliki suatu makna dan tujuan sebagai bahan komunikasi dan informasi yang tercatat di kertas, media komputer dan lembaran fotocopy. Da ri defnisi diatas dapat didefinisikan bahwa arsip adalah kumpulan naskah atau dokumen dari berbagai kegiatan atau organisasi yang disimpan aman dan teratur agar lebih mudah dicari ketika diperlukan. (Hartono \& Wardani, 2019). Saat ini proses yang digunakan untuk mengarsipkan surat menyurat masih menggunakan cara manual membutuhkan waktu 10-15 menit untuk proses pengarsipan surat-surat yang ada.

Untuk menangani masalah tersebut dibutuhkan suatu aplikasi yang dapat membantu pengarsipan surat secara elektronik berbasis web.

Web merupakan layanan penyedia informasi dengan konsep hyperlink yang mempermudah pengguna melakukan penelusuran informasi di internet. Informasi yang disajikan menggunakan konsep multimedia, informasi dapat disajikan dengan menggunakan berbagai macam media, seperti teks, suara, film, animasi, atau gambar.

(Masykur et al., 2015). Aplikasi berbasis web yag dirancang ini bertujuan untuk meningkatkan ketepatan, efisiensi, dan keamanan surat dan mempermudah kinerja akademik dalam proses pengarsipan surat di Universitas Nasional terutama pada unit Tata Usaha (TU). Berdasarkan latar belakang tersebut, maka peneliti tertarik dalam pembuatan aplikasi ini. Adapun aplikasi yang akan peneliti buat berjudul "Aplikasi Elektronik Arsip (EArsip) Berbasis Web dengan Metode First In First Out (FIFO)".

Metode First In First Out (FIFO) adalah metode dimana surat yang pertama kali masuk ke Aplikasi akan dikerjakan pertama kali pula dalam penanganannya. (Sinaga et al., 2017) Berdasarkan latar belakang diatas maka permasalahan yang dirumuskan peneliti Pengarsipan hanya untuk pengarsipan surat masuk dan surat keluar saja, untuk pengarsipan jenis lainnya seperti dokumen lain dilakukan dalam pengembangan selanjutnya.

Tujuan peneliti melakukan penelitian yaitu untuk merancang dan membuat aplikasi elektronik arsip (e-arsip) surat berbasis web dengan metode first in first out (FIFO) di Universitas Nasional, untuk membantu unit tata usaha dalampr oses surat menyurat sehingga menghindari antrian yang menumpuk dari surat yang masuk dan surat keluar. aplikasi e-arsip ini dapat bermanfaat bagi peneliti maupun instansi (unit kerja) yang terkait yaitu meningkatkan efisiensi, ketepatan dan keamanan surat yang diarsipkan,mempermudah dan mempercepat unit kerja melakukan proses pengarsipan surat masuk dan surat keluar di Universitas dengan adanya aplikasi digital terdapatnya salinan arsip dalam bentuk elektronik, terjamin terekamnya informasi yang terkandung dalam lembaran arsip, emudahan akses terhadap arsip elektronik,kecepatan penyajian informasi, keamanan akses dan memiliki fasilitas backup arsip penting.

\section{METODOLOGI PENELITIAN}

\section{Jenis dan Sumber Data}

Berikut jenis data yang digunakan peneliti :

1. Jenis Data

a. Data primer adalah data yang diperoleh secara langsung dengan melihat Aplikasi yang sudah berjalan pada proses surat masuk dan surat keluar di Universitas Nasional.

b. Data sekunder adalah data yang diperoleh dengan cara melakukan penelitian kepustakaan. Dan datanya berupa buku-buku, artikel-artikel dan jurnal yang menjadi pendukung dalam pembuatan aplikasi pada penelitian ini.

\section{Sumber Data}

Pada penelitian ini peneliti mendapatkan sumber data menggunakan metode pengumpulan data sebagai berikut:

a. Wawancara (Interview)

Wawancara merupakan pengumpulan data yang dilakukan secara langsung dengan narasumber atau orang yang akan diwawancarai. Adapun data-data yang didapatkan dalam penelitian ini dilakukan dengan cara wawancara atau bertanya secara langsung kepada unit Tata Usaha (TU) di Universitas Nasional.

b. Observasi (Field research) 
Observasi adalah pengamatan langsung para pembuat keputusan berikut lingkungan fisiknya atau pengamatan langsung suatu kegiatan yang sedang berjalan. Pada tahap ini peneliti melakukan pengamatan terhadap kegiatan dan proses surat di Universitas Nasional.

c. Kepustakaan (Library research)

Kepustakaan merupakan kegiatan mengumpulkan data yang diperoleh dari buku-buku atau artikelartikel. Pada tahap ini peneliti mengumpulkan buku-buku atau artikel terkait sesuai dengan penelitian.

\section{Metode Perancangan Aplikasi}

Berdasarkan latar belakang masalah dan tujuan peneliatan maka metode penelitian yang digunakan yaitu metode waterfall. Metode waterfall merupakan model pengembangan Aplikasi informasi yang tersusun Aplikasiatik dan teratur secara sekuensial. (Suryadi, 2019) Model waterfall adalah suatu proses pengembangan perangkat lunak Aplikasiatis yang berurutan,dimana kemajuan dilihat dari proses yang terus mengalir seperti air terjun dengan melewati fase-fase analisis, desain, pengkodean dan pengujian. (Hatta et al., 2019) Model ini digambarkan sebagai berikut :

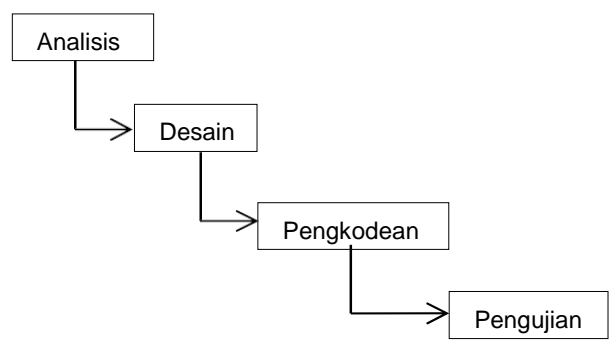

Sumber: (Hatta et al., 2019)

\section{Gambar 1. Model Waterfall}

Sesuai dengan perancangan aplikasi menggunakan waterfall, Aplikasi informasi e-arsip ini dimulai dengan cara sebagai berikut:

1. Analisis kebutuhan Aplikasi terdiri dari analisis hardware, software, dan komponen lain yang terkait.

2. Desain Aplikasi mencakup penggunaan software yang digunakan seperti bahasa pemodelan flowchart diagram.

3. Implementasi Aplikasi dengan cara menulis kode program sesuai dengan desain yang telah dirancang sebelumnya.

4. Pengujian Aplikasi menggunakan metode black box. (Yulianto, 2019)

Model penelitian waterfall ini diuraikan sebagai be rikut:

\section{Analisis Kebutuhan Aplikasi}

Analisis kebutuhan Aplikasi dalam penelitian ini tujuannya menganalisa kebutuhan user dalam menggunakan Aplikasi nantinya. Adapun analisis kebutuhan Aplikasi didapat dengan cara dengan observasi dan wawancara langsung dengan staf pada unit Tata Usaha di Universitas Nasional. Hasil yang didapat berupa data kuantitatif dan kualitatif yang dibutuhkan dalam pengembangan software.

\section{Desain Aplikasi}

Desain Aplikasi yaitu gambaran dari analisis kebutuhan. Desain Aplikasi digambarkan dalam bentuk flowchart diagram. Proses desain Aplikasi menggunakan flowchart ini dibagi menjadi 3 bagian yaitu dari flowchart unit pembuat surat, flowchart unit penerima surat dan flowchart unit terkait.

\section{Implementasi Aplikasi}

Tahap selanjutnya adalah implementasi dari d esain yang telah dibuat secara nyata kedalam bahasa pemrograman atau code. Pada Aplikasi ini implementasi dibuat kedalam bahasa pemrograman PHP, database MySQL, framework Codeigniter dan framework Bootstrap.

\section{Pengujian Aplikasi}

Aplikasi yang sudah selesai dibuat dan memenuhi fungsi-fungsi yang dibutuhkan akan diuji menggunakan metode black box testing. Black box testing atau yang biasa disebut dengan pengujian fungsional merupakan metode pengujian perangkat lunak yang digunakan untuk menguji kelayakan tanpa mengetahui struktur internal kode atau program (Yulianto, 2019).

\section{Teknik Analisis Data}

Dalam melakukan penelitian, peneliti menggunakan teknik analisis deskriptif kualitatif yaitu suatu metode penelitian yang bersifat nyata atau fakta sesuai dengan data yang diperoleh dengan tujuan untuk mengetahui proses dan alur kegiatan surat di Universitas Nasional.

\section{Analisis Aplikasi}

Analisis Aplikasi adalah proses mengumpulkan da $\mathrm{n}$ menginterpretasikan realitas yang ada, mendiagnosa persoalan untuk memperbaiki Aplikasi. Dalam tahap ini peneliti melakukan:

1. Mengidentifikasi masalah untuk mendapat pengertian sebenarnya dari masalah yang dihadapi yaitu dengan mengidentifikasikan penyebab masalah dan bagaimana langkah untuk menyelesaikannya.

2. Memahami Aplikasi kerja yang ada dengan mengumpulkan data hasil penelitian dan memahami Aplikasi yang ada. 
3. Menganalisa kelemahan Aplikasi dan kebutuhan informasi.

\section{HASIL DAN PEMBAHASAN}

\section{Perancangan Aplikasi}

Berdasarkan hasil pengamatan analisa Aplikasi maka dibuat Aplikasi berjalan dan Aplikasi usulan dengan bentuk Flowchart Diagram. Flowchart Diagram digunakan untuk menggambarkan alur Aplikasi pada penelitian ini. Adapun flowchart Aplikasi usulan penelitian ini sebagai berikut :

\section{Proses Surat Menyurat yang Berjalan}

Proses yang berjalan dalam pengarsipan surat di Universitas Nasional masih belum terkomputerisasi. Penyimpanan masih secara manual memungkinkan data hilang, rusak dan menyulitkan dalam melakukan pencarian data jika suatu waktu diperlukan.

Berikut Aplikasi berjalan surat menyurat pada Universitas Nasional :

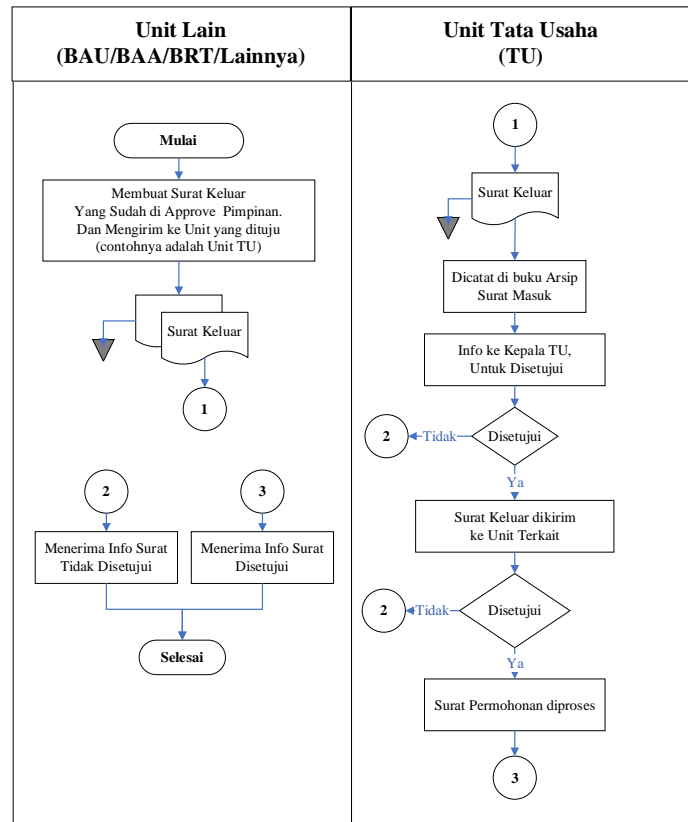

Gambar 2. Flowchart Surat Menyurat Pada Universita Nasional

1. Aplikasi Usulan

Aplikasi Usulan yang dibuat yaitu terdiri dari flowchart Unit Pembuat Surat, Unit Penerima Surat dan Unit Terkait. Berikut ini flowchart diagram tersebut:

a. Flowchart Unit Pembuat Surat

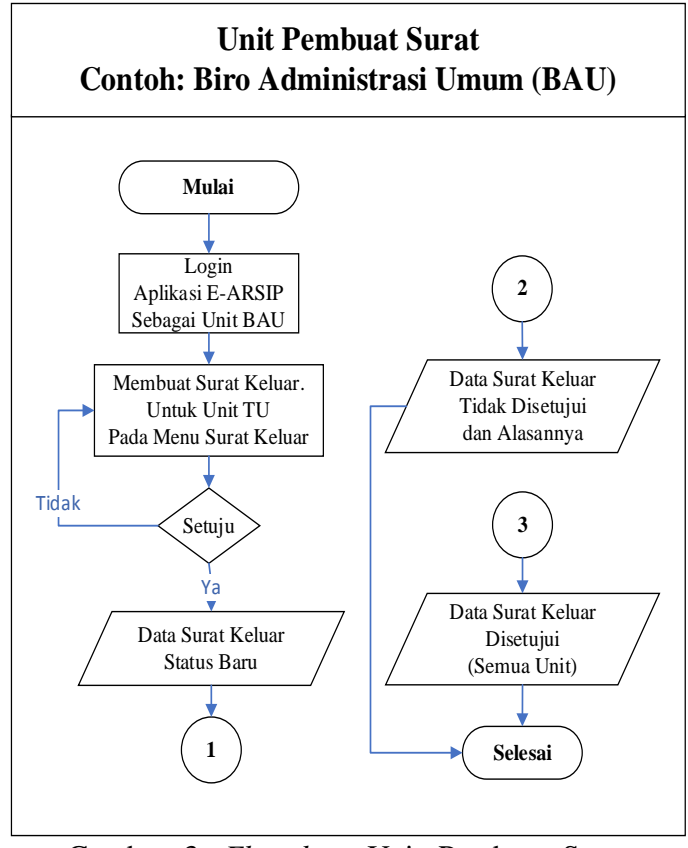

Gambar 3. Flowchart Unit Pembuat Surat

b. Flowchart Unit Penerima Surat

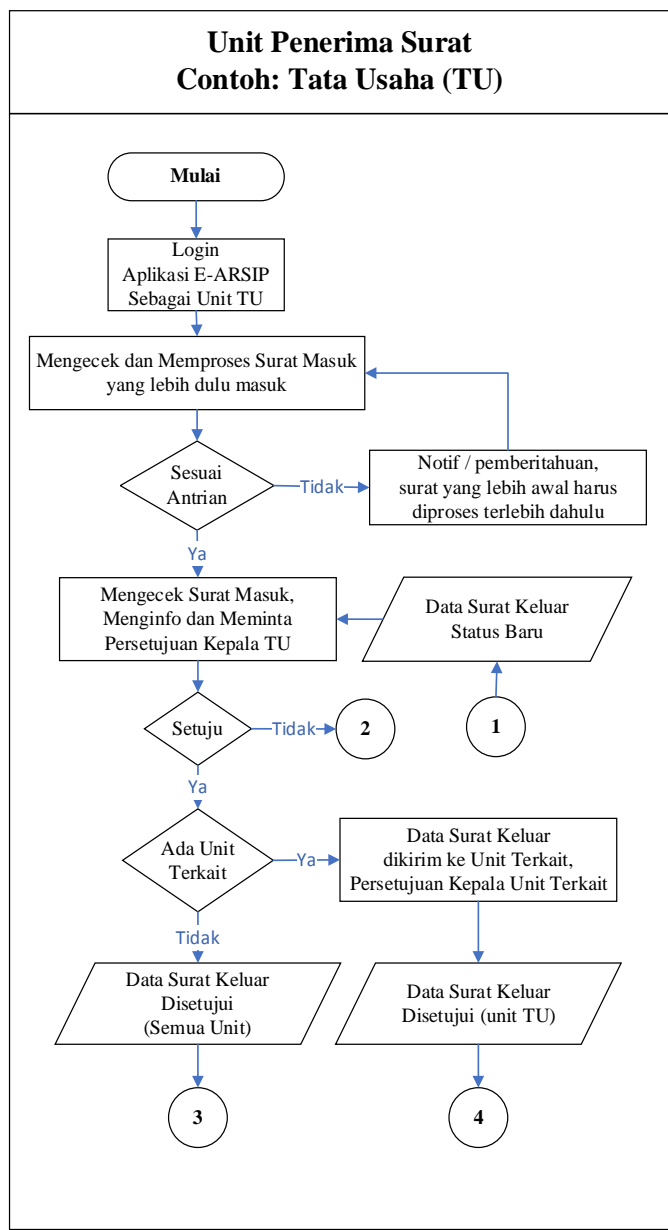

Gambar 4. Flowchart Unit Penerima Surat 


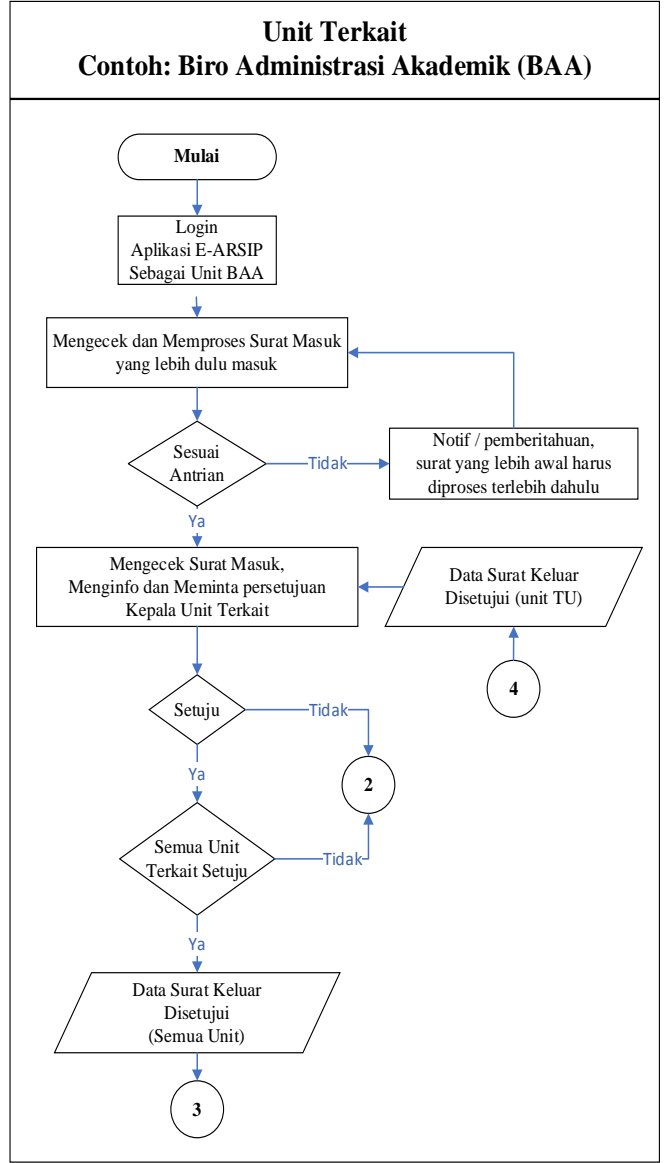

Gambar 5. Flowchart Unit Terkait

\section{Rancangan Desain Aplikasi}

Adapun perancangan desain aplikasi yang akan dibuat sebagai berikut :

1. Halaman Login

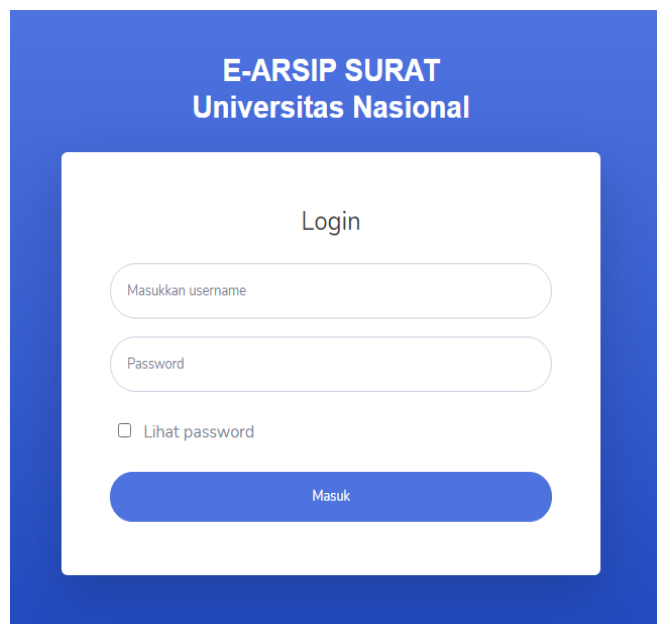

Gambar 6. Halaman Login

Pada halaman login, form input username $e$ mail dan password sebagai validasi untuk mengunakan aplikasi e-arsip.

2. Halaman Dashboard

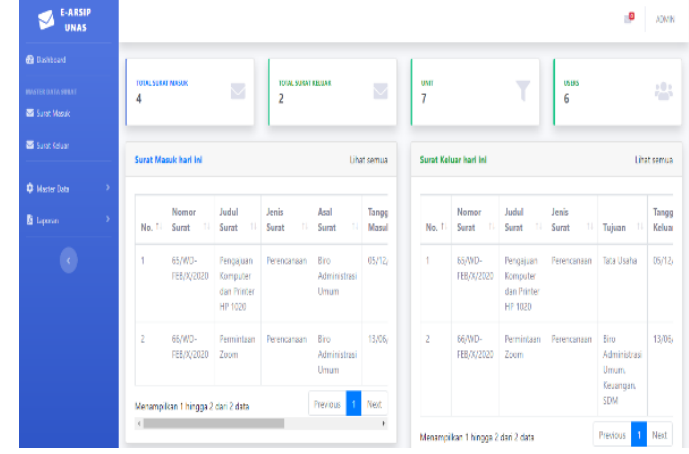

Gambar 7. Halaman Dashboard

Pada halaman dashboard menampilkan keseluruhan jumlah data surat masuk, surat keluar, data user. Dan menampilkan surat masuk dan surat keluar hari ini.

3. Halaman Surat Masuk

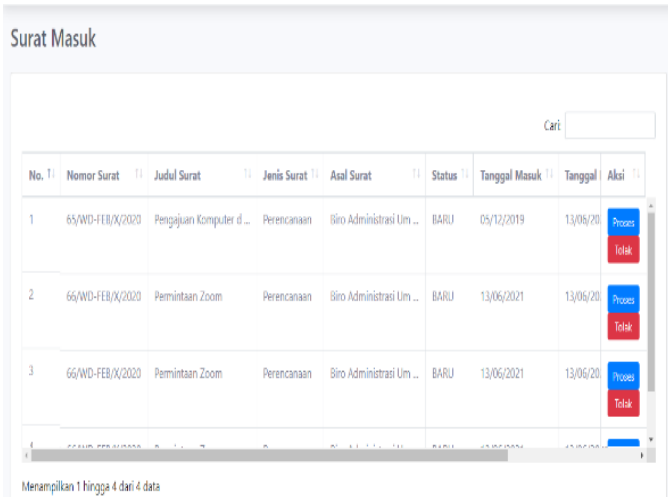

Gambar 8. Halaman Surat Masuk

Pada halaman surat masuk menampilkan data surat masuk masuk, manage data surat masuk dan pemberitahuan surat masuk dan terdapat notifikasi jika surat yang diproses tidak sesuai antrian.

4. Halaman Surat Keluar

Surat Keluar
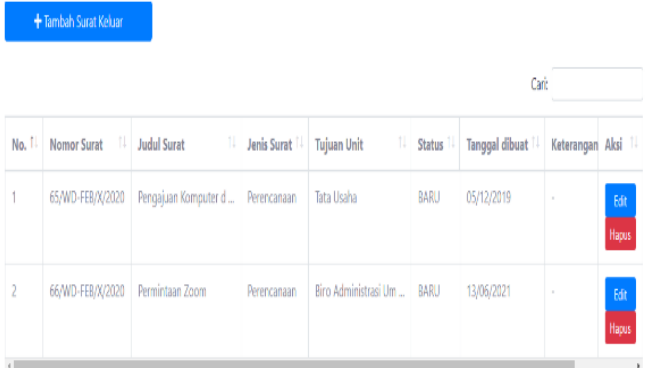

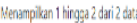

Gambar 9. Halaman Surat Keluar 
Pada halaman surat keluar menampilkan data surat keluar, menambah data, edit data dan delete data surat keluar.

5. Form Tambah Surat Keluar

Tambah Data

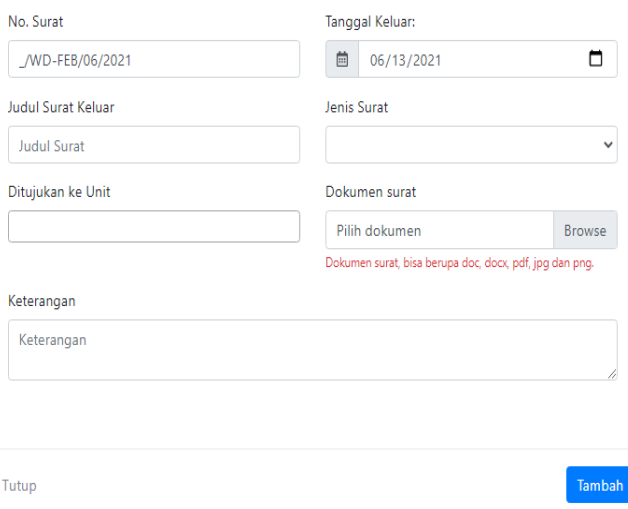

Gambar 10. Halaman Manage Surat Keluar

Pada form tambah surat keluar, terdapat inputan yang harus diisi yaitu: no surat, judul surat, keterangan, dituju ke unit, tanggal keluar, upload file surat keluar yang sudah disetujui.

6. Halaman Data User

$$
\text { Data Users }
$$
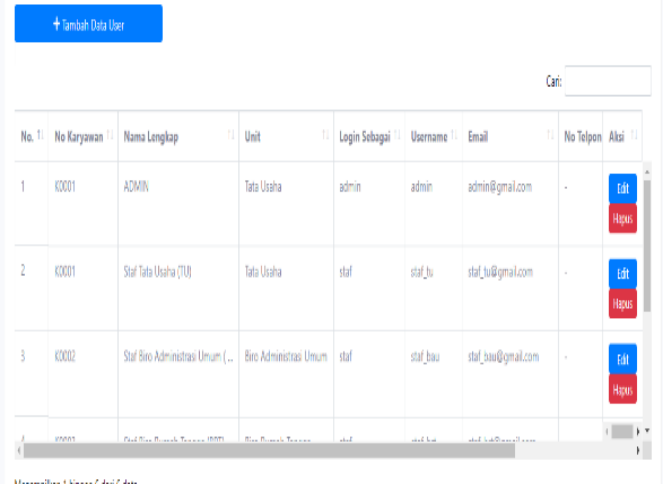

Gambar 11. Halaman Data User

Pada halaman user menampilkan data user dan dapat menambah user, edit user dan delete user dan melihat profil user.

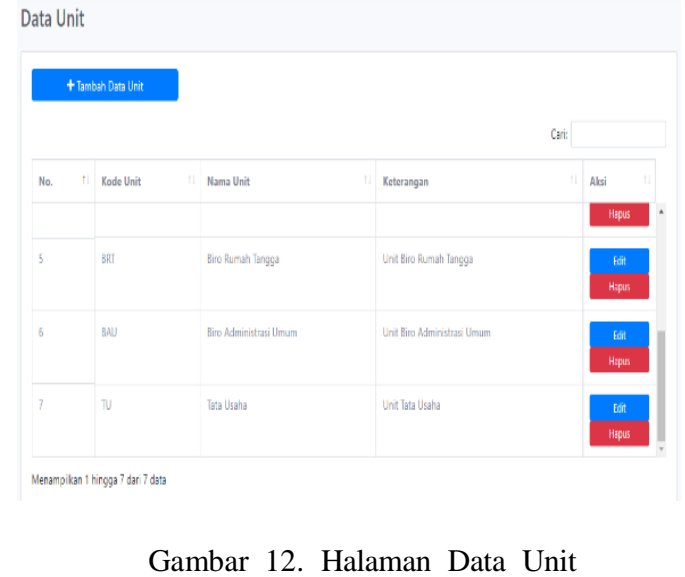

Pada halaman data unit menampilkan data unit dan dapat menambah unit, edit unit dan delete unit.

8. Halaman Data Jenis Surat

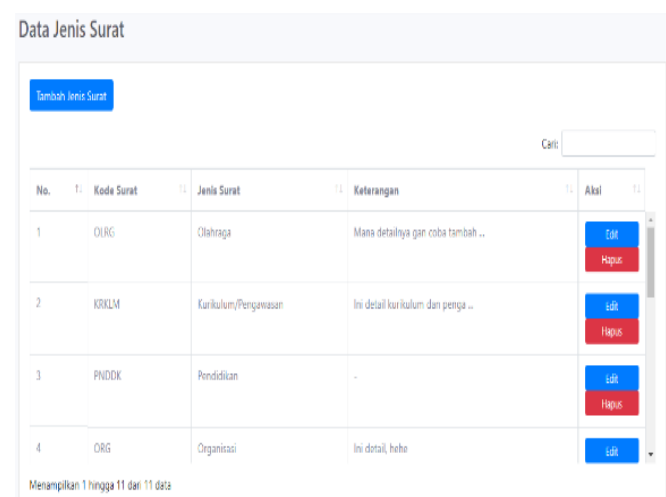

Gambar 13. Halaman Data Jenis Surat

Pada halaman unit menampilkan data jenis surat dan dapat menambah, edit dan delete jenis surat.

9. Halaman Laporan Surat Masuk

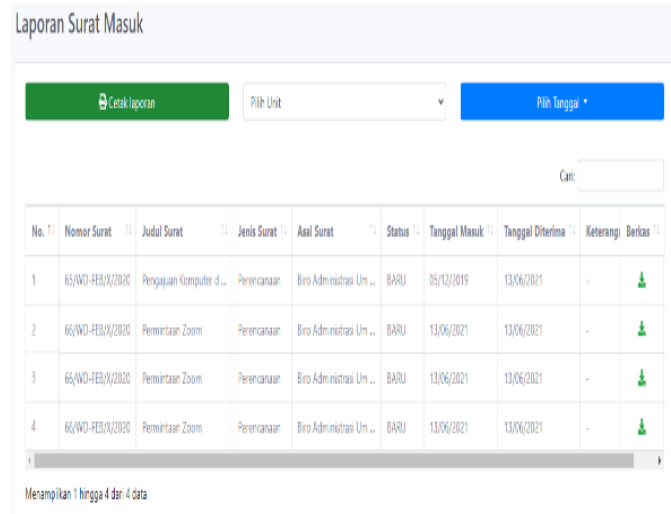

Gambar 14. Halaman Laporan Surat Masuk

7. Halaman Data Unit 
Pada halaman laporan surat masuk menampilkan data laporan surat masuk, melihat dan mencetak surat masuk selama periode tertentu.

10. Halaman Laporan Surat Keluar Laporan Surat Keluar

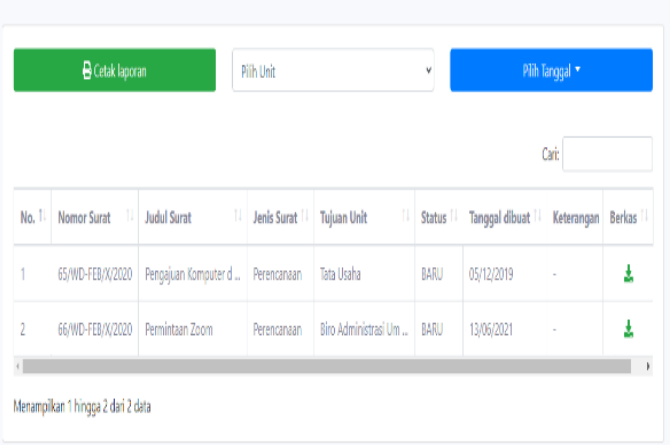

Gambar 15. Halaman Laporan Surat Keluar

Pada halaman laporan surat keluar menampilkan data laporan surat keluar, melihat dan mencetak surat keluar selama periode tertentu.

\section{Hasil Pengujian}

Setelah rancangan aplikasi selesai, maka dilakukan sebuah pengujian. Pengujian aplikasi tersebut dilakukan dengan menggunakan Black Box Testing. Berikut tabel hasil pengujian aplikasi :

Tabel 1. Tabel Hasil Pengujian Aplikasi

\begin{tabular}{|c|l|c|c|}
\hline \multirow{2}{*}{ No. } & \multicolumn{1}{|c|}{ Fungsi } & \multicolumn{2}{c|}{$\begin{array}{c}\text { Aplikasi Valid } \\
\text { Non Valid }\end{array}$} \\
\cline { 3 - 5 } & & Ya & Tidak \\
\hline A. & Akun & & \\
\hline 1 & Login user & $\sqrt{ }$ & \\
\hline 2 & Mengubah Password & $\sqrt{ }$ & \\
\hline 3 & Logout & $\sqrt{ }$ & \\
\hline B. & Pengelolaan Data User & & \\
\hline 5 & Melihat data user & $\sqrt{ }$ & \\
\hline 6 & Menambah data user & $\sqrt{ }$ & \\
\hline 7 & Mengedit data user & $\sqrt{ }$ & \\
\hline 8 & Menghapus data user & $\sqrt{ }$ & \\
\hline C. & Pengelolaan Data Unit & & \\
\hline 9 & Melihat data unit & $\sqrt{ }$ & \\
\hline 6 & Menambah data unit & $\sqrt{ }$ & \\
\hline 7 & Mengedit data unit & $\sqrt{ }$ & \\
\hline 8 & Menghapus data unit & $\sqrt{ }$ & \\
\hline D. & Pengelolaan Data Jenis Surat & & \\
\hline 9 & Melihat data jenis surat & $\sqrt{ }$ & \\
\hline & & & \\
\hline
\end{tabular}

\begin{tabular}{|l|l|c|l|}
\hline 10 & Menambah data jenis surat & $\sqrt{ }$ & \\
\hline 11 & Mengedit data jenis surat & $\sqrt{ }$ & \\
\hline 12 & Menghapus data jenis surat & $\sqrt{ }$ & \\
\hline E. & Pengelolaan Data Surat Masuk & & \\
\hline 13 & Validasi Surat Masuk diproses & $\sqrt{ }$ & \\
\hline 14 & Proses persetujuan kepala unit & $\sqrt{ }$ & \\
\hline 15 & Proses persetujuan unit terkait & $\sqrt{ }$ & \\
\hline F. & Pengelolaan Data Surat Keluar & & \\
\hline 16 & Melihat data surat keluar & $\sqrt{ }$ & \\
\hline 17 & Menambah data surat keluar & $\sqrt{ }$ & \\
\hline 18 & Mengedit data surat keluar & $\sqrt{ }$ & \\
\hline 19 & Menghapus data surat keluar & $\sqrt{ }$ & \\
\hline G. & Pengelolaan Laporan & & \\
\hline 20 & Mencetak laporan surat masuk & $\sqrt{ }$ & \\
\hline 21 & Mencetak laporan surat keluar & $\sqrt{ }$ & \\
\hline
\end{tabular}

Sumber: (Yulianto, 2019)

\section{KESIMPULAN}

Berdasarkan hasil pengujian aplikasi di atas, bahwa aplikasi telah lulus uji dan aplikasi elektronik arsip (e-arsip) surat berbasis web dengan metode First In First Out (FIFO) di Universitas Nasional sudah bisa digunakan sesuai dengan tujuannya. Dan dari 1000 jumlah data statistik surat masuk dan keluar yang semakin besar tiap tahunnya bisa diatasi dengan aplikasi e-arsip ini.

\section{REFERENSI}

Hartono, E., \& Wardani, N. W. (2019). Aplikasi Pengarsipan Surat Masuk Surat Keluar Digital Berbasis Web. Jurnal Teknologi Informasi Dan Komputer, 5(2), 204-211. https://doi.org/10.36002/jutik.v5i2.787

Hatta, M., Anwar, M. M., Diana, I. N., \& Amarul M, M. H. (2019). Perancangan Aplikasi Informasi Pengarsipan Dan Disposisi Surat Berbasis Web Dengan Menggunakan Framework Codeigniter. SCAN - Jurnal Teknologi Informasi Dan Komunikasi, $14(2)$. https://doi.org/10.33005/scan.v14i2.1481

Hendrayudi. (2013). VB 2008 Untuk Berbagai Keperluan Pemrograman (1st ed.). PT. Elex Media Komputindo.

Masykur, F., Makruf, I., \& Atmaja, P. (2015). Aplikasi Administrasi Pengelolaan Arsip Surat Masuk Dan Surat Keluar Berbasis Web. Indonesian Journal on Networking and Security, 4(3), 1-7.

Sinaga, A. T., Syahrizal, M., \& Panjaitan, M. (2017). Aplikasi Simulasi Antrian Pembayaran Pajak 
Kendaraan Bermotor Menggunakan Metode First In First Out (FIFO) (Studi Kasus Samsat Tamiang). Pelita Informatika, 16(3), 256-262.

Suryadi, A. (2019). Rancang Bangun Aplikasi Pengelolaan Arsip Surat Berbasis Web Menggunakan Metode Waterfall (Studi Kasus : Kantor Desa Karangrau Banyumas). Jurnal Khatulistiwa Informatika, 7(1), 13-21. https://doi.org/10.31294/jki.v7i1.36

Yulianto, R. W. (2019). Pengembangan (SISMAKA) Aplikasi Informasi Surat Masuk Dan Surat Keluar Berbasis Web Pada Kantor Kelurahan Sukorejo Semarang. Jurnal Ilmiah Cendekia Eksakta, 2(1), 101-111.

\section{PROFIL PENELITI}

Wahyu Suratman merupakan mahasiswa aktif Fakultas Teknologi Komunikasi dan Informatika di Universitas Nasional. Saat ini sedang menempuh pendidikan S1.

Fauziah merupakan dosen aktif Fakultas Teknologi Komunikasi dan Informatika di Universitas Nasional.

Ratih Titi Komala Sari merupakan dosen aktif Fakultas Teknologi Komunikasi dan Informatika di Universitas Nasional. 